\title{
Pemberantasan Rabies di Indonesia sebagai Upaya Mewujudkan Right to Life, Right to Health
}

\section{The Eradication of Rabies in Indonesia as Achieving the Right to Life and the Right to Health}

\author{
Risqa Novita* \\ Puslitbang Biomedis dan Teknologi Dasar Kesehatan, Badan Litbang Kesehatan Kemenkes RI \\ Jalan Percetakan Negara 23 Jakarta, Indonesia \\ *E_mail: rn_smile01@yahoo.com
}

Received date: 25-03-2019, Revised date: 29-07-2019, Accepted date: 11-10-2019

\begin{abstract}
ABSTRAK
Rabies termasuk salah satu penyakit menular dari hewan ke manusia yang mendapat perhatian serius oleh Pemerintah berkaitan dengan angka kematian yang cukup tinggi pada manusia. Sebanyak 26 provinsi di Indonesia belum bebas dari rabies hingga tahun 2017. Tujuan penulisan sistematik review ini untuk mengetahui pengaruh hukum kesehatan masyarakat di Indonesia terhadap pelaksanaan pemberantasan rabies di Indonesia, dan untuk mewujudkan right to life and right to health dalam menyatukan berbagai aspek yang berpengaruh terhadap pemberantasan rabies di Indonesia agar tujuan Indonesia untuk bebas dari rabies pada tahun 2030 dapat tercapai. Perundang-undangan di Indonesia yang ada saat ini sudah cukup lengkap sebagai aspek legal, payung hukum terhadap pelaksanaan pemberantasan rabies. Namun, implementasi peraturan-peraturan tersebut belum dilakukan sepenuhnya karena peraturan tersebut pada umumnya dibuat oleh Pemerintah Pusat, sedangkan pelaksanaan berada di Pemerintah Daerah yang belum semua daerah memiliki Peraturan Daerah (Perda) yang mengatur pelaksanaan pemberantasan rabies, sehingga perlu adanya Perda sebagai payung pelaksanaan pemberantasan rabies di daerah. Hukum kesehatan masyarakat berpengaruh terhadap pelaksanaan pemberantasan rabies di Indonesia, dan untuk mewujudkan right to life and right to health dalam menyatukan berbagai aspek yang berpengaruh terhadap pemberantasan rabies di Indonesia agar tujuan Indonesia untuk bebas dari rabies pada tahun 2030 dapat tercapai.
\end{abstract}

Kata kunci: rabies, Indonesia, hak untuk hidup, hak untuk sehat, zoonosis

\begin{abstract}
Rabies is one of infectious diseases from animals to man which gets serious attention from the government due to its high mortality in human.Until 2017, as many as 26 provinces in Indonesia has not been free from Rabies yet. The purposes of this writing are to uncover the influence of health law of the people in Indonesia on the implementation of rabies eradication in Indonesia. Beside, this could be used by the policy makers to unity programs to realize people's right to life, right to health toward Indonesia being free from rabies in 2030. The current legislations are considered sufficient, but not their implementations. The regulations are mostly made by the central government, while the local government are the implementor. Local regultaions, therefore, are needed as umbrella for the eradication program in the areas. To conclude, public health and other laws have influenced the eradication efforts of the disease. Public health law influences the implementation of eradication of rabies in Indonesia, and to realize right to life and right to health in bringing together various aspects that influence the eradication of rabies in Indonesia so that the goal of Indonesia to be free from rabies in 2030 can be achieved.
\end{abstract}

Keywords: rabies, Indonesia, right to life, right to health, zoonoses 


\section{PENDAHULUAN}

Tiap-tiap manusia memiliki hak untuk hidup sejak dari kandungan karena manusia sudah memiliki tujuan penciptaan. Hak untuk hidup merupakan hak dasar bagi tiap manusia yang mendorong terbentuknya hak dasar manusia lainnya. ${ }^{1}$

Deklarasi Universal Tahun 1944 tentang Hak-hak Asasi Manusia menyebutkan bahwa tiap orang mempunyai hak untuk hidup pada standar yang layak untuk kesehatan dan kesejahteraan mereka serta keluarga mereka, termasuk hak untuk mendapat makanan, perumahan dan pelayanan kesehatan. Hak manusia merupakan bagian dari hukum internasional, yakni tiap-tiap manusia memiliki hak dasar, tanpa memandang diskriminasi ras, warna kulit, agama, status ekonomi, bahasa, kebangsaan, gender, etnis dan lain-lain., ${ }^{1,2}$

Undang-Undang Dasar 1945 pasal 28 menyatakan bahwa setiap manusia memiliki hak untuk hidup dan mempertahankan hidup dan kehidupannya serta disebutkan hak-hak asasi manusia lainnya, antara lain hak untuk melanjutkan keturunan, bebas dari kekerasan dan diskriminasi, mendapatkan pendidikan yang layak, mendapatkan jaminan dan perlindungan hukum, mendapatkan kesempatan yang sama dalam pemerintahan, beragama, berkomunikasi, hidup sejahtera lahir dan batin, bertempat tinggal dan mendapatkan lingkungan hidup yang baik dan sehat serta memperoleh pelayanan kesehatan, dan setiap orang wajib menghormati hak asasi manusia lain dalam tertib kehidupan bermasyarakat, berbangsa dan bernegara. ${ }^{3}$

Hukum kesehatan terbagi atas dua bagian yaitu Hukum Kesehatan Masyarakat dan Hukum Kedokteran. Hukum kesehatan masyarakat lebih menitikberatkan pada pelayanan kesehatan masyarakat atau mencakup pelayananan kesehatan rumah sakit, sedangkan untuk hukum kedokteran lebih memilih atau mengatur tentang pelayanan kesehatan individual tetapi menyangkut tentang pelayanan kesehatan. ${ }^{2}$

Untuk mewujudkan derajat kesehatan yang optimal bagi setiap orang, yang merupakan bagian integral dari kesejahteraan, diperlukan dukungan hukum bagi penyelenggaraan berbagai kegiatan di bidang kesehatan. Hukum kesehatan masyarakat mengatur tentang kesehatan masyarakat misalnya tentang tindakan preventif, wabah maupun karantina. ${ }^{2}$

Saat ini kasus penularan penyakit dari hewan ke manusia masih merupakan ancaman yang serius terhadap kesehatan masyarakat. Salah satu penyakit asal hewan yang masih berbahaya bagi manusia adalah rabies. Kirakira sebanyak 55.000 manusia meninggal tiap tahunnya di dunia akibat Rabies, dan 45\% berasal dari Asia Tenggara. ${ }^{4}$

Rabies di Indonesia telah menyebar di 25 provinsi sampai dengan tahun 2017. Berdasarkan data dari Ditjen Pencegahan dan Pengendalian Penyakit (P2P) Direktorat Pengendalian Penyakit Tular Vektor Zoonotik, pada tahun 2017 kasus kematian akibat Rabies (Lyssa virus) mengalami penurunan sekitar 27,12\%. Kasus Gigitan Hewan Penular Rabies (GHPR) di tahun 2016 hanya turun sekitar 19,44\% menjadi 64.774 laporan. $^{5}$

Jumlah provinsi bebas rabies sampai dengan 2017 sebanyak 9 provinsi, yaitu 5 provinsi bebas historis (Papua, Papua Barat, Bangka Belitung, Kepulauan Riau, dan Nusa Tenggara Barat) dan 4 provinsi dibebaskan (Jawa Tengah, Daerah Istimewa Yogyakarta, Jawa Timur, dan DKI Jakarta). ${ }^{5}$ Kondisi ini memerlukan perencanaan strategis yang lebih matang terhadap 26 provinsi di Indonesia yang masih endemis.

Rabies ada di Indonesia sejak abad ke 18. Penyebab virus rabies di Indonesia berasal dari kasus rabies yang ada di pulau Jawa yaitu di daerah Cirebon. Virus tersebut dapat menyebar ke seluruh wilayah Indonesia melalui perpindahan HPR yang ada di Jawa. Kasus rabies di Nias berasal dari virus rabies di Sumatera, sedangkan kasus rabies di Bali berasal dari virus rabies di Kalimantan. Hal ini berarti bahwa HPR di Bali tertular dari HPR yang datang dari Kalimantan., 
Terdapat beberapa indikator yang digunakan dalam memantau upaya pengendalian rabies yaitu: kasus Gigitan Hewan Pembawa Rabies (GHPR), kasus yang diberi vaksinasi post exposure treatment dengan Vaksin Anti Rabies (VAR) dan kasus yang meninggal karena Rabies (Lyssa) dan spesimen positif pada hewan. Penentuan suatu daerah dikatakan tertular rabies berdasarkan hasil pemeriksaan laboratorium hewan, dan kewenangan ini ditentukan oleh Kementerian Pertanian. ${ }^{5,6}$

Penyebaran virus rabies di dalam tubuh hospes sulit dihentikan karena kecepatan penyebarannya tiga milimeter per jam. Terkait dengan hal itu, masa inkubasi rabies dapat mencapai 1 tahun tergantung dari lokasi gigitan. Makin jauh lokasi gigitan dari kepala, maka masa inkubasi rabies akan semakin lama, begitupula dengan sebaliknya. Rabies disebabkan oleh Lyssa Virus, yang termasuk dalam Famili Rhabdoviridae. Penularan rabies melalui gigitan hewan berdarah panas seperti anjing, kucing, serta monyet, dan melalui kontaminasi membran mukosa, mata, udara dan transplantasi organ. ${ }^{7-10}$

Upaya penanggulangan rabies yang efektif saat ini terbatas pada vaksinasi rabies pada reservoir atau Hewan Pembawa Rabies (HPR). Upaya lainnya adalah pembatasan populasi reservoir atau HPR, yaitu dengan mengurangi jumlah anjing liar yang berkeliaran di lingkungan. ${ }^{9}$

Mengingat besarnya masalah rabies dengan tingkat kematian yang tinggi rabies dapat diprioritaskan kedua untuk diberantas setelah Avian Influenza. ${ }^{5}$ Tujuan penulisan ini adalah untuk mengetahui pengaruh hukum kesehatan masyarakat terhadap pelaksanaan pemberantasan rabies di Indonesia, dan untuk mewujudkan right to life and right to health dalam menyatukan berbagai aspek yang berpengaruh terhadap pemberantasan rabies di Indonesia.

\section{METODE}

Penelusuran kepustakaan dilakukan melalui internet dengan memakai peramban Google dan PubMed. Penelusuran menggunakan kata kunci rabies di Indonesia. Kepustakaan diambil dari unduhan jurnal gratis dan laman situs kesehatan internasional seperti World Health Organization (WHO).

Kriteria inklusi rujukan adalah semua artikel dan teks mengenai rabies di Indonesia secara umum dengan total referensi sebanyak 50 buah. Pemilahan kepustakaan lalu difokuskan pada produk hukum pemberantasan rabies di Indonesia. Setelah melalui penelusuran melalui sistematika di atas, terpilih referensi yang diambil sebagai acuan penulisan ini yang mencakup artikel produk hukum, artikel tinjauan pustaka dan 3 laman berisi artikel ilmiah dengan jumlah keseluruhan pustaka yang didapatkan sejumlah 35 .

\section{PEMBAHASAN}

Pada umumnya tiap bangsa di dunia mengalami tiga tahap pembangunan, yaitu unification, industrialization dan social welfare. Hukum, institusi hukum dan sarjana hukum memiliki peranan penting untuk membawa perubahan kepada sistem norma dan nilai baru di tiap-tiap tahap pembangunan itu. Oleh karena itu sangat diperlukan legalitas hukum yang berupa peraturan perundangundangan agar usaha pemberantasan rabies di Indonesia dapat berjalan efektif dan efisien. ${ }^{1,2}$

Pemerintah telah memiliki program nasional yaitu Indonesia bebas rabies pada Tahun 2030 , namun hingga Tahun 2018, hanya 9 provinsi di Indonesia yang bebas dari rabies, sedangkan pada Tahun 2019 ini, provinsi bebas rabies berkurang menjadi 8 provinsi, ketika Nusa Tenggara Barat terjadi kasus rabies pada bulan Januari-Maret 2019, yang menyebabkan kematian manusia sebesar 14 orang. ${ }^{11}$

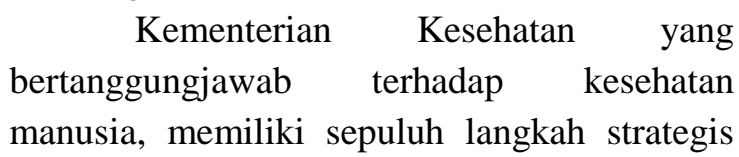


untuk menuju Indonesia bebas rabies, yaitu : (a) sosialisasi; (b) penguatan regulasi; (c) komunikasi risiko; (d) pengembangan atau peningkatan kapasitas; (e) vaksinasi massal pada HPR; (f) manajemen populasi HPR; (g) profilaksis pra/ paska gigitan HPR (PEP); (h) surveilans dan respon terpadu; (i) penelitian operasional dan (j) kemitraan. $^{5}$ Selain termasuk di dalam langkah strategis tersebut, regulasi juga termasuk di dalam empat pendekatan untuk pengendalian rabies yang disepakati oleh semua negara ASEAN yaitu poin pendekatan legislatif. ${ }^{5,11}$

Aspek legislatif dituangkan dalam bentuk regulasi sebagai upaya untuk melaksanakan pembangunan kesehatan, karena pemberantasan rabies secara optimal dapat diwujudkan dengan melaksanakan pembangunan kesehatan lintas sektoral. Pembangunan kesehatan sangat penting untuk mewujudkan derajat kesehatan masyarakat yang setingi-tingginya, ditandai dengan umur harapan hidup tiap warga negara yang panjang. ${ }^{5,8}$

\section{Right to Life and Right to Health}

Hak untuk hidup sehat, secara khusus ada di dalam Deklarasi Universal tentang HakHak Asasi Manusia yang menyebutkan bahwa tiap orang mempunyai hak untuk hidup pada standar yang layak untuk kesehatan dan kesejahteraan mereka, dan keluarga mereka, termasuk hak untuk mendapat makanan, perumahan, dan pelayanan kesehatan. ${ }^{1}$

Dalam memenuhi hak untuk hidup dan hak untuk sehat, diperlukan payung hukum agar dapat terlaksana. Di dalam kasus penularan penyakit dari hewan ke manusia, atau biasa disebut zoonosis memerlukan suatu hukum kesehatan. Hukum kesehatan merupakan ketentuan yang mengatur mengenai kesehatan manusia, di dalamnya terdapat hukum kedokteran, hukum kesehatan masyarakat, hukum kesehatan lingkungan, dan hukum kesehatan lainnya. $^{2}$

Data Badan Kesehatan Dunia (WHO) menunjukkan rata-rata di Asia ada 50.000 kasus kematian akibat rabies per tahun. Kasus di negara Asia terbanyak ditemukan di India (20.000-30.000 kasus per tahun), Vietnam (rata-rata 9.000 kasus per tahun), China (ratarata 2.500 kasus per tahun), Filipina (200-300 kasus per tahun) dan Indonesia (rata-rata 125 kasus pertahun). ${ }^{5,9}$

Kasus rabies di Indonesia sebagian besar disebabkan oleh gigitan anjing sebanyak 98\% dan sebagian kecil disebabkan oleh gigitan monyet dan kucing yaitu $2 \%$. Kasus gigitan akibat hewan penular rabies (HPR) di seluruh Indonesia sampai saat ini telah mencapai lebih dari 12.000 kasus gigitan (GHPR). ${ }^{5}$

Data dari Kementerian Kesehatan hingga tahun 2017 menunjukkan rabies telah menyebar di 25 provinsi, sedangkan pada awal tahun 2019, telah menyebar di 26 provinsi. Dua puluh lima provinsi yang terdapat kasus rabies yaitu Nanggroe Aceh Darussalam, Sumatera Utara, Sumatera Barat, Riau, Kepulauan Riau, Jambi, Sumatera Selatan, Bengkulu, Lampung, Banten, Jawa Barat, Bali, Nusa Tenggara Timur, Sulawesi Utara, Gorontalo, Sulawesi Tengah, Sulawesi Tenggara, Sulawesi Selatan, Sulawesi Barat, Kalimantan Selatan, Kalimantan Timur, Maluku, Maluku Utara dan Kalimantan Tengah. Rabies sering menimbulkan kejadian luar biasa (KLB). Tahun 2005 KLB terjadi di provinsi Maluku, Maluku Utara dan Kalimantan Barat. Akhir Tahun 2007, KLB terjadi di Banten. Pada November 2008 KLB terjadi di Kab.Badung, Bali. ${ }^{5,9,12-16}$

Kasus GHPR di Pulau Nias, Sumatera Utara sampai dengan Juli 2010 terjadi 857 kasus GHPR. Sekitar 815 orang diberi vaksin anti rabies atau VAR, sedangkan 42 orang tidak mendapat VAR. Dari 857 kasus GHPR tersebut, 23 orang diantaranya meninggal dunia. $^{17}$

Kasus rabies menyebar tahun $2008 \mathrm{di}$ Bali, yaitu di Kabupaten Badung. Hingga bulan Agustus 2010 terdapat 53.418 kasus GPHR, 83 orang di antaranya meninggal (4 orang tahun 2008, 26 orang tahun 2009, dan 53 orang tahun 2010). Kasus rabies di Bali ditemukan pertama kali pada 18 November 
2008 dengan korban meninggal dunia setelah digigit anjing. ${ }^{6,7,9}$

\section{Produk Hukum Terkait Pemberantasan Rabies}

Hukum kesehatan yang pada saat ini sebenarnya terbagi atas dua bagian yaitu diantaranya Hukum Kesehatan Masyarakat dan Hukum Kedokteran. ${ }^{2}$ Untuk mewujudkan masyarakat Indonesia yang sehat maka perlu adanya pengaturan tentang pelayanan kesehatan dan demi menjamin hak dari setiap orang yaitu hak untuk hidup yang merupakan salah satu hak asasi yang dipegang oleh manusia., ${ }^{2,118}$ Beberapa produk hukum yang mengatur tentang kesehatan masyarakat, antara lain:

1. Undang-Undang Nomor 18 Tahun 2009 tentang Peternakan dan Kesehatan Hewan di dalam Undang-Undang Peternakan dan Kesehatan Hewan tahun 2009 sebagaimana diubah dalam UU No 41 Tahun 2014 dicantumkan mengenai kesehatan hewan, yaitu bagaimana cara untuk mengatasi penyakit hewan menular dan juga dibahas mengenai kesehatan masyarakat veteriner yang mengatur usaha-usaha kesehatan hewan dan produk asal hewan untuk mewujudkan kesehatan masyarakat. Penanganan kasus rabies juga dibahas karena berpengaruh terhadap kesehatan manusia. $^{19}$

2. Undang-Undang No 36 Tahun 2009 tentang Kesehatan

Dicantumkan bahwa kesehatan adalah keadaan sehat baik secara fisik, mental, spiritual maupun sosial yang memungkinkan setiap orang untuk hidup produktif secara sosial dan ekonomis. Menurut pasal 152 pasal (1) disebutkan bahwa Pemerintah, Pemerintah Daerah dan masyarakat bertanggungjawab atas pencegahan, dan pemberantasan penyakit menular serta akibat yang ditimbulkannya. Dalam hal ini rabies merupakan salah satu penyakit menular. Pada ayat (3) Upaya pencegahan, pemberantasan penyakit menular dapat dilaksanakan melalui kegiatan promotif. $^{20}$

3. Peraturan Pemerintah No 40 Tahun 1991 tentang Penanggulangan Wabah Penyakit Menular

Di dalam pasal 10 dicantumkan bahwa upaya penanggulangan wabah meliputi penyelidikan epidemiologis, pemeriksaan, pengobatan, perawatan dan isolasi penderita. ${ }^{21}$

4. Undang-Undang Republik Indonesia No 16 Tahun 1992 tentang Karantina Hewan, Ikan dan Tumbuhan

Undang-undang ini tercantum perlunya karantina hewan sebelum memasuki wilayah Indonesia untuk diketahui status kesehatannya. Lalu lintas hewan antar daerah juga diatur oleh Undang-Undang ini, sehingga seyogyanya perpindahan hewan dari daerah endemis rabies ke daerah bebas rabies di Indonesia, seyogyanya tidak terjadi. ${ }^{22}$

Di dalam buku petunjuk pelaksanaan dan penatalaksanaan kasus gigitan hewan tersangka rabies di Indonesia, disebutkan bahwa rabies merupakan penyakit zoonosis yang terpenting karena sering menimbulkan kematian bagi manusia, sehingga tidak cukup upaya pencegahan dan pemberantasan, tetapi harus diupayakan pemberantasan wilayah terhadap rabies. ${ }^{23}$

Pembebasan rabies bukan hanya tanggungjawab Kementerian Kesehatan, Kementerian Pertanian dan Kementerian Dalam Negeri saja, namun Kementerian Lingkungan Hidup dan Kehutanan serta Kementerian Koordinator Pembangunan Manusia dan Kebudayaan Republik Indonesia juga memiliki peran.

\section{Program Pembebasan Rabies dan Produk Hukumnya}

Rabies merupakan penyakit dari virus yang sangat mematikan bagi manusia dan hewan. Pada akhir tahun 2008 Provinsi Bali yang semula bebas sudah menjadi daerah tertular rabies. Kasus rabies mengalami 
peningkatan di Bali, Nias dan Maluku Tenggara Barat sebanyak 165 kasus. Kasus terbanyak terdapat di Bali yaitu 119 kasus, disusul Nias 26 kasus dan Pulau Lara Maluku Tenggara Barat 20 kasus. Oleh adanya peningkatan kasus dan kematian, maka ketiga wilayah tersebut dinyatakan terjadi Kejadian Luar Biasa (KLB) rabies. Sepanjang tahun 2010 secara nasional telah terjadi 74.858 kasus GHPR, 195 kasus di antaranya berakhir pada kematian. ${ }^{5,6,10,24}$

Mengingat bahaya rabies terhadap kesehatan dan ketentraman masyarakat memiliki dampak buruk yaitu selalu diakhiri kematian, serta dapat mempengaruhi perekonomian khususnya bagi pengembangan daerah-daerah pariwisata di Indonesia yang tertular rabies, maka rabies dapat mengancam right to life and right to health masyarakat Indonesia. Oleh karena itu, telah dilaksanakan program pembebasan rabies yang merupakan kesepakatan nasional dan merupakan kerjasama kegiatan tiga Kementerian, yaitu Kementerian Pertanian (Ditjen Peternakan dan Kesehatan Hewan), Kementerian Dalam Negeri (Ditjen PUM) dan Kementerian Kesehatan (Ditjen PP dan PL) sejak awal Pelita V tahun 1989. ${ }^{5,10}$

Untuk mewujudkan masyarakat Indonesia yang sehat maka adanya pengaturan tentang pelayanan kesehatan dan untuk menjamin hak dari setiap orang yaitu hak hidup sehat yang merupakan salah satu hak asasi yang dimiliki oleh manusia. Untuk mewujudkan hal ini diperlukan beberapa produk hukum, antara lain:

1. Undang-Undang Republik Indonesia No 36 tahun 2009 Tentang Kesehatan

Di dalam Undang-Undang ini dibahas banyak mengenai kesehatan. Rabies disinggung dalam Bab VI mengenai Upaya Kesehatan, pasal 46-51, disebutkan bahwa untuk mewujudkan derajat kesehatan yang setinggi-tingginya bagi masyarakat, diselenggarakan upaya kesehatan yang terpadu dan menyeluruh dalam bentuk upaya kesehatan perorangan dan upaya kesehatan masyarakat dalam bentuk kegiatan dengan pendekatan promotif, preventif, kuratif dan rehabilitatif dilaksanakan secara terpadu, menyeluruh dan berkesinambungan. Untuk menjalankan upaya kesehatan ini diperlukan kerjasama antara pemerintah, pemerintah daerah dan masyarakat. ${ }^{20}$

2. Undang-Undang Peternakan dan Kesehatan Hewan No 18 tahun 2009 sebagaimana diubah dalam UU No 41 tahun 2014

Di dalam Undang-Undang ini dibahas mengenai Upaya-Upaya Kesehatan Hewan dan Kegiatan Surveilans Penyakit Zoonosis. ${ }^{19}$

3. Peraturan Menteri Kesehatan No 1116 Tahun 2003 Tentang Pedoman Penyelenggaraan Sistem Surveilans Epidemiologi Kesehatan

Di dalam Peraturan ini dicantumkan mengenai metode surveilans untuk menanggulangi penyakit menular dan kejadian luar biasa. ${ }^{25}$

4. Peraturan Pemerintah No 40 Tahun 1991 Tentang Penanggulangan Wabah Menular Disebutkan bahwa penanggulangan wabah penyakit menular merupakan bagian dari pembangunan kesehatan. ${ }^{26}$

Dalam menanggulangi rabies Kementerian Kesehatan bekerjasama dengan WHO mengeluarkan beberapa kebijakan sebagai berikut :

1. Pemberantasan rabies di daerah tertular dengan menyediakan vaksin anti rabies (VAR) untuk manusia, menyediakan media penyuluhan, meningkatkan pengetahuan dan ketrampilan petugas kesehatan melalui pelatihan dokter/paramedis Puskesmas dan klinik swasta di 6 Kabupaten/Kota serta membantu kebutuhan VAR untuk hewan sebanyak 120.000 dosis.

2. Melakukan surveillans aktif

3. Mendirikan "Rabies Center" di daerah tertular yaitu Puskesmas atau Rumah Sakit yang ditunjuk Dinas Kesehatan setempat sebagai pusat informasi dan penanganan kasus gigitan hewan penular rabies. ${ }^{5,6,18,19,27-}$ 31 
Produk hukum yang berupa perundang-undangan maupun peraturan menteri sudah cukup baik, dalam arti dapat menjadi acuan dan payung hukum dalam pelaksanaan pemberantasan rabies, namun angka kematian manusia akibat rabies meningkat tiap tahun, dan Bali menjadi daerah tertular padahal sebelumnya Bali merupakan daerah bebas historis. ${ }^{5,32}$

Belum berhasilnya program pemberantasan rabies dapat disebabkan oleh beberapa faktor penghambat, misalnya keterbatasan dana untuk program pemberantasannya. Hal ini dapat dimengerti karena rabies merupakan penyakit yang terabaikan (neglected diseases), sehingga anggaran yang dikeluarkan untuk pengendalian rabies terbatas, berbeda dengan dana pengendalian rabies yang disarankan oleh WHO. Hal ini membutuhkan naskah akademis untuk penglegitimasian pengendalian rabies sehingga membutuhkan dukungan dana untuk kegiatan tersebut.. ${ }^{4,26,33}$

Kurangnya dana ini menyebabkan kegiatan pemberantasan rabies menjadi terhambat, karena biaya operasional rabies cukup besar dan melibatkan lintas sektoral antara Kementerian Kesehatan, Kementerian Pertanian, Kementerian Lingkungan Hidup dan Kehutanan, Kementerian Koordinator Pembangunan Manusia dan Kebudayaan serta Kementerian Dalam Negeri.

Faktor penghambat lainnya adalah adanya konsep sehat dalam masyarakat, yang menurut para pengambil keputusan dan masyarakat masih sebagai konsep sakit. Konsep sakit adalah apabila telah jatuh sakit, baru memikirkan tentang sehat. ${ }^{8}$

Penanggulangan rabies memerlukan proses desentralisasi, karena pemerintah daerah dan masyarakat memiliki tanggungjawab..$^{25,34}$ Kelemahan di Indonesia, payung hukum untuk pemberantasan rabies hanya berada di pusat, yang berupa UndangUndang Kesehatan, Undang-Undang Peternakan dan Kesehatan Hewan, Peraturan Pemerintah, Keputusan Menteri Kesehatan dan Keputusan Menteri Pertanian. Namun, di tingkat daerah masih belum banyak daerah yang mengakomodasi payung hukum tersebut dalam bentuk Peraturan Daerah (Perda). Padahal dalam proses desentralisasi ini, diharapkan tiap daerah dapat membuat model, skenario, dan indikator pencapaian yang dapat disesuaikan dengan kondisi, tempat, waktu, dan latar belakang sosial. Namun di era otonomi daerah ini, peranan dinas yang bertanggungjawab terhadap kesehatan hewan juga mengalami penurunan. Hal ini karena bersatunya berbagai dinas dalam satu kesatuan, sehingga peranan masing-masing dinas menjadi mengecil. ${ }^{2,8,17}$

Tiap-tiap daerah seharusnya sudah memiliki Perda tentang penanganan rabies, terutama provinsi-provinsi yang belum bebas rabies. Namun pada kenyataannya tidak seperti itu, sebagai contoh Kotamadya $\mathrm{X}$ hanya memiliki Peraturan daerah No 9 Tahun 2004 tentang pemeliharaan hewan ternak berkaki empat yang hanya membahas ketentuan pemeliharaan hewan ternak berkaki empat saja, tidak termasuk kewajiban vaksinasi rabies untuk anjing, kucing dan kera. ${ }^{17,18}$ Hal tersebut berakibat pemilik hewan tidak merasa memiliki kewajiban untuk memvaksinasi hewan peliharaannya karena tidak ada peraturan legal yang mewajibkan untuk memvaksinasi rabies hewan peliharaannya, sehingga berakibat banyak anjing, kucing dan monyet tidak divaksin rabies yang rentan.

Daerah yang memiliki Perda untuk pemberantasan adalah Bali, dituangkan dalam Perda No. 15 Tahun 2009. ${ }^{19}$ Perda ini juga memuat agar pemilik anjing untuk mengandangkan anjing atau mengikat anjing agar tidak berkeliaran. Hal ini diperlukan agar anjing sebagai induk semang utama tidak dapat menyebar virus rabies ke lingkungan, sehingga penyebaran virus rabies akan terbatas. Pengandangan anjing juga diperlukan untuk mempermudah pemberian vaksin rabies ke anjing. ${ }^{20}$

Kelemahan lainnya, seharusnya dibuat peraturan daerah bersama yang membahas mengenai konsep One Health di tingkat pusat hingga daerah, dan tidak hanya melibatkan 
Dinas Kesehatan dan Dinas Peternakan, sehingga penanggulangan rabies dapat terintegrasi. Hal tersebut diharapkan agar penanggulangan rabies tidak berjalan sendirisendiri seperti saat ini, yang berakibat penyelesaian kasus rabies belum komprehensif sehingga korban manusia akibat rabies terus mengalami peningkatan. ${ }^{19}$

Peraturan Daerah dapat menjadi acuan teknis untuk pelaksanaan pengendalian rabies, namun usia perda sebaiknya tidak terlalu lama agar dapat sesuai dengan kondisi terkini sehingga acuan pelaksanaan akan mudah diimplementasikan. Hal ini melihat dari Perda Bali No 15 Tahun 2009 yang pada Tahun 2018 dinilai sudah kurang relevan lagi, sehingga dapat diusulkan perda pengganti yang lebih relevan baik di tingkat kabupaten/kota maupun tingkat provinsi, disesuaikan dengan perubahan peraturan perundangan di atasnya yaitu mengacu pada UU No 41 Tahun 2014 tentang Peternakan dan Kesehatan Hewan, UU No 36 Tahun 2009 tentang Kesehatan, PP No 95 Tahun 2012 tentang Kesehatan Masyarakat Veteriner dan Kesejahteraan Hewan, dan PP No 47 Tahun 2014 tentang Pengendalian dan Penanggulangan Penyakit Hewan. ${ }^{19}$ Aspek yang dinilai lebih relevan dapat dimasukkan di dalam Perda pengganti tersebut, misalnya menyangkut sosiokultural di tiap-tiap daerah yang berbeda. Misalnya di Bali, pemeliharaan anjing tidak akan bisa efektif dilaksanakan di tengah masyarakat Bali yang secara turun temurun terbiasa hidup berdampingan dengan anjing yang dipelihara secara dilepas liarkan, sehingga Pasal 5 ayat 1(e) dan (f) Perda Bali No 15 Tahun 2009 tentang pemeliharaan anjing secara dikandangkan atau diikat perlu dikaji ulang, oleh karena Perda tersebut tidak efektif karena belum sesuai dengan sosio budaya masyarakat di Bali, sehingga kasus rabies di Bali belum mengalami penurunan secara signifikan.

Pengendalian populasi anjing sebagai HPR sangat perlu dilakukan agar virus rabies tidak dapat bersirkulasi di dalam lingkungan. Pengendalian populasi anjing melalui program sterilisasi massal dapat dimasukkan di dalam
Perda pengganti. Usaha pemberantasan kasus rabies harus dimasukkan di dalam pembangunan kesehatan manusia, sehingga untuk melegitimasikan itu diperlukan substansi hukum, yaitu penguatan badan legislatif, yudikatif dan eksekutif harus dilakukan sehingga tercapai tujuan pembangunan kesehatan. $^{8} \quad$ Usaha pemberantasan rabies yang hingga saat ini masih dinilai efektif adalah melakukan vaksinasi pada HPR. ${ }^{21}$

Suatu Undang-Undang atau Peraturan daerah yang diajukan oleh badan eksekutif maupun legislatif dapat mengakomodasi tujuan pembangunan kesehatan tersebut. Dalam meluluskan suatu Perda, sebaiknya DPRD memiliki tenaga ahli di berbagai bidang, terutama bidang zoonosis atau penyakit hewan menular ke manusia. ${ }^{17,19}$

\section{Right to Life and Right to Health pada Usaha Pemberantasan Rabies}

Inti makin meluasnya kasus rabies di Indonesia adalah kurangnya kerjasama dari masyarakat, terhambat oleh berbagai budaya setempat dan kurangnya kerjasama lintas sektoral. Oleh karena itu perlu memasukkan aspek hukum dan hak asasi manusia dalam upaya pemberantasan kasus rabies di Indonesia agar terdapat efek jera bagi yang melanggar. ${ }^{1,2}$

Peranan masyarakat perlu dimasukkan di dalam aspek legal, sehingga pengendalian rabies tidak hanya dilakukan oleh pihak pemerintah saja sehingga aspek legal berupa peraturan yang telah dibuat dapat lebih mudah diimplementasikan. Peran masyarakat sangat membantu pengendalian rabies, seperti terjadi di Kroasia. Masyarakat dilibatkan untuk membantu mengendalikan rabies, salah satunya dengan vaksinansi pada HPR melalui oral. Masyarakat yang paham mengenai pentingnya rabies setelah diberi sosialisasi mengenai vaksinasi rabies, secara sadar dan sukarela aktif membantu pelaksanaan vaksinasi rabies pada HPR. Pelaksanaan vaksinasi dilaksanakan rutin selama 32 bulan dan membuat kroasia mendapatkan pengakuan 
bebas rabies dari Office Internationale des Epizootica (OIE) atau organisasi kesehatan hewan dunia. ${ }^{22}$

Sosialisasi pada masyarakat sebaiknya dilakukan pada waktu yang ideal, merujuk kesuksesan pada kasus di Kroasia, dilakukan pada saat tidak ditemukan lagi kasus positif rabies di lapangan dan juga membicarakan tentang keberhasilan penanggulangan rabies di negara lain, dalam hal ini Kroasia mencontoh pelaksaan penanggulangan rabies di negara Baltik, yaitu memakai peran serta masyarakat untuk membantu pelaksanaan vaksinasi rabies pada reservoirnya. ${ }^{23}$

Berbagai produk hukum telah dibuat oleh Pemerintah pusat terkait oleh fungsi pemerintah pusat yaitu bertanggungjawab terhadap pengendalian penyakit menular strategis. Namun untuk mendukung tercapainya program pemberantasan rabies diperlukan suatu produk hukum yang bersifat lokal agar partisipasi masyarakat daerah dapat dilakukan, hal ini perlu diperhatikan mengingat masyarakat Indonesia memiliki sosio budaya yang berbeda antar wilayah. Misalnya di Bali, untuk pengendalian rabies tidak cukup hanya dengan pengendalian di HPR berupa vaksinasi dan pengandangan HPR. Pemberian promosi kesehatan di masyarakat juga sangat diperlukan. ${ }^{24}$

Promosi kesehatan ini diharapkan dapat meningkatkan pengetahuan masyarakat mengenai bahaya rabies terhadap kelangsungan hidup manusia, dan mengubah perilaku masyarakat agar mengerti dan membantu program pemerintah untuk mengendalikan rabies. Pelaksanaan program pengendalian rabies yang berupa produk hukum lokal harus dilakukan monitoring secara terus menerus oleh Pemerintah Daerah agar efektif dan mencapai sasaran. ${ }^{25}$

Produk hukum lokal tersebut dapat berupa Peraturan Daerah (Perda). Bagi daerah yang belum memiliki Perda tentang rabies dapat diusulkan untuk pembuatan Perda. Dalam pembuatan Perda diperlukan peranan seorang perencana pembangunan kesehatan dalam hal pembuatan naskah akademis.
Naskah akademis adalah naskah yang dapat dipertanggungjawabkan secara ilmiah mengenai konsepsi yang berisi latar belakang, tujuan penyusunan, sasaran yang ingin diwujudkan dan lingkup, jangkauan, objek atau arah rancangan undang-undang. ${ }^{26}$

Naskah akademis memiliki kedudukan sebagai dasar secara ilmiah bahwasanya upaya pemberantasan rabies memang layak untuk mendapatkan pengaturan. Jika naskah akademis sudah terbentuk maka tahap selanjutnya dalam penyusunan Perda adalah pembentukan Tim antar Satuan Kerja Perangkat Daerah (SKPD) dan pembahasan Rancangan Peradaturan Daerah (Raperda) dengan biro hukum, kemudian Raperda yang telah dibahas harus mendapat paraf koordinasi Kepala biro Hukum dan pimpinan SKPD terkait, selanjutnya pimpinan SKPD mengajukan Raperda yang telah mendapatkan paraf ke Kepala Daerah melalui sekretaris daerah dan langkah terakhir yaitu Kepala Daerah mengajukan Raperda tersebut ke DPRD untuk dilakukan pembahasan. ${ }^{26-29}$

Jika Perda sudah terbentuk maka fungsi otonomi daerah dapat berjalan optimal, karena penanganan bidang kesehatan merupakan kewajiban daerah dalam rangka otonomi daerah. Agar sistem hukum yang tercipta dapat berjalan, kita memerlukan budaya hukum. Budaya hukum adalah persepsi masyarakat tentang hukum dan sistem hukum, pandangan, nilai, ide, dan penghargaan masyarakat terhadap hukum. ${ }^{2}$

Jika sistem hukum telah berjalan sesuai koridornya, maka usaha pemberantasan kasus rabies dapat dijalankan di segala lapisan masyarakat secara optimal, karena akan terdapat sanksi bagi mereka yang melanggar. Hal ini akan membuat kesejahteraan sosial akan meningkat. ${ }^{2}$ Budaya hukum tiap daerah berbeda-beda dan hal inilah yang mendasari kebijakan tiap daerah harus berbeda, meskipun memiliki tujuan yang sama yaitu pembebasan rabies. ${ }^{2,30}$

Kasus rabies pada manusia sebagian disebabkan oleh gigitan anjing, sehingga eliminasi rabies pada anjing merupakan suatu 
langkah utama yang diprioritaskan. ${ }^{21}$ Negara di dunia yang belum bebas rabies sebagian besar memilih vaksinasi rabies pada HPR sebagai upaya pengendalian strategis, namun vaksinasi rabies pada HPR ini bukan langkah tunggal yang diprioritaskan. Sosio budaya masyarakat dan status ekonomi masyarakat adalah faktor lain yang juga harus diperhatikan dalam pemberantasan rabies, sehingga produk hukum pengendalian rabies seyogyanya menjangkau semua lini, mulai dari HPR, termasuk vaksinasi dan pemeliharaan, hingga masyarakat, termasuk sosio budaya dan tingkat perekonomian masyarakat di tiap-tiap daerah. ${ }^{31}$

\section{KESIMPULAN}

$\begin{array}{ccc}\text { Hukum } & \begin{array}{c}\text { kesehatan } \\ \text { berpengaruh }\end{array} & \begin{array}{r}\text { masyarakat } \\ \text { terhadap }\end{array}\end{array}$ pemberantasan rabies di Indonesia, dan untuk mewujudkan right to life and right to health dalam menyatukan berbagai aspek yang berpengaruh terhadap pemberantasan rabies di Indonesia agar tujuan Indonesia untuk bebas dari rabies pada tahun 2030 dapat tercapai.

\section{DAFTAR PUSTAKA}

1. Atkinson Jeff. APEC-Winner and Losser. Australian Council for Overseas Aid (ACFOAC). 1995.

2. Dewi, Alexandria I. Etika dan hukum kesehatan. Yogyakarta: Pustaka Publisher; 2008.

3. Sekretariat Jenderal DPR RI. Undang-Undang Dasar Republik Indonesia Tahun 1945. Jakarta; 2016. Diunduh dari: http://www.dpr.go.id/jdih/uu1945.

4. WHO. Strategic framework for elimination human rabies transmitted by dogs in SouthEast Asia Region. New Delhi: World Health Organization Regional Office for South-East Asia; 2012. p. 1-50.

5. Kementerian Kesehatan RI. Infodatin: situasi rabies di indonesia [Internet]. Jakarta: Kementerian Kesehatan RI; 2017 [cited 2017 Des 21]. Available from: http:// www.pusdatin.kemkes.go.id/resources/downl oad/ pusdatin/infodatin/infodatin-Rabies2017.pdfDitjen P2PL. Bali, Nias dan Maluku Tenggara terjadi KLB Rabies. Direktorat Jenderal Pemberantasan Penyakit dan
Penyehatan Lingkungan. Kementerian Kesehatan RI. 2011.

6. Dibia IN, Sumiarto B,Susetya H, Putra AAG, Scott-Orr H, Mahardika GN. Phylogeography of the current rabies viruses in Indonesia. Journal of Veterinary Science. 2015;16(4):459-66. doi: 10.4142/jvs.2015.16.4.459.

7. Susetya H, Sugiyama $\mathrm{M}$, Inagaki $\mathrm{A}$, Ito N, Mudiarto G, Minamoto N. Molecular epidemiology of rabies in Indonesia. Virus research. 2008;135(1):144-9.

8. El Tholoth M, El-Beskawy M, Hamed MF. Identification and genetic characterization of rabies virus from Egyptian water buffaloes (Bubalus bubalis) bitten by a fox. VirusDis. 2015; 26(3):141-6. doi: 10.1007/s13337-0150263-y.

9. Susilawathi N.M, Darwinata AE, Dwija IB, Budayanti NS, Wirasandhi GA, Subrata K, et al. Epidemiological and clinical features of human rabies cases in Bali 2008-2010. BMC Infectious Diseases. 2012;12(81):1-9. doi: 10.1186/1471-2334-12-81.

10. Laura B, Cobianchi M, Breda T, Favero L, Ruocco L, Marangon S. Sylvatic rabies epidemic in Italy: implementation of a data management system to assess the level of application of preventive dog vaccination. Pathogens and Global Health. 2013;107(7):354-60. doi: 10.1179/2047772413Z.000000000176.

11. Kementerian Kesehatan RI. Kebijakan rabies. Jakarta: Direktorat Pengendalian dan Pencegahan Penyakit. Kementerian Kesehatan RI; 2019.

12. Hanlon CA. Rabies in terrestrial animals. In: Jackson AC, editor. Rabies - scientific basis of the disease and its management. Boston (MA): Academic Press; 2013. p. 179-213.

13. Gyanendra G, E.Wright A. Human rabies in the WHO Southeast Asia Region: forward steps for elimination. SAGE; 2011.15. doi:10.4061/2011/383870.

14. Wartapedia. Rabies di Indonesia 125 kasus per tahun [Internet]. [cited 2011 Nov 7] Available from: http:// Rabies Prioritas Kedua Setelah Avian Influenza, Depkes RI. 2011.

15. Anfasa MF. Pembangunan berkelanjutan dalam peningkatan derajat kesehatan manusia. 
Seminar Pembangunan Hukum Nasional VIII. Denpasar: Departemen Hukum dan Hak Asasi manusia; 2014.

16. Vallat B. The OIE's commitment to fight rabies worldwide. Rabies: a priority for humans and animals. Bull Off Int epizoot. $2011 ; 3: 1-2$.

17. Eka S, Misriyah, Ma'ruf A, Setyanti $\mathrm{T}$, Laporan penanggulangan KLB rabies di Pulau Nias Sumatera Utara. [Laporan]. Subdit Zoonosis, Direktorat Jenderal Pemberantasan Penyakit dan Penyehatan Lingkungan: Kementerian Kesehatan ; 2010.

18. Yemi O, Olukonyisola. Human rights and economic development in developing countries. The International Lawyer. 1994;28(3).

19. Undang- Undang Nomor 18 Tahun 2009 Tentang Peternakan dan Kesehatan Hewan. Diunduh dari: http://ditjennak.pertanian.go.id/userfiles/regul asi/85453cb4e07dc5422595300f5d9a890f.pdf

20. Undang-Undang Nomor 36 Tahun 2009 Tentang Kesehatan. Diunduh dari: https://jdih.kemenkeu.go.id/fullText/2009/36 TAHUN2009UU.htm.

21. Peraturan Pemerintah No 40 Tahun 1991 Tentang Penanggulangan Wabah Penyakit Menular. Diunduh dari: http://www.bphn.go.id/data/documents/91pp0 40.pdf.

22. Undang-Undang Republik Indonesia No 16 Tahun 1992 Tentang Karantina Hewan, Ikan dan Tumbuhan. Diunduh dari: http://kkji.kp3k.kkp.go.id/index.php/dokumen /regulasi-hukum/undang-undang/undangundang-kelautan-dan-perikanan/finish/10 undang-undang-kelautan-dan-perikanan/95uu-no-16-tahun-1992-karantina-hewan-ikandan-tumbuhan.

23. Direktorat Jenderal PPM dan PL. Petunjuk pelaksanaan dan penatalaksanaan kasus gigitan hewan tersangka rabies di Indonesia. Departemen Kesehatan RI. 2000;Edisi ke VI.

24. Maya MN, Yovani N. Menuju Indonesia bebas rabies 2020: problem institusi dalam implementasi kebijakan kesehatan publik di Bali. Jurnal Kebijakan Kesehatan Indonesia.2018;7(4):168-72.
25. Keputusan Menteri Kesehatan RI No 1116 Tahun 2003 tentang Pedoman Penyelenggaraan Sistem Surveilans Epidemiologi Kesehatan. Diunduh dari: http://pdk3mi.org/file/download/KMK\%20No .\%201116\%20ttg\%20Pedoman\%20Penyeleng garaan $\% 20$ Sistem $\% 20$ Surveilans $\% 20$ Epidemi ologi\%20Kesehatan.pdf.

26. Peraturan Pemerintah No 40 Tahun 1991 Tentang Penanggulangan Wabah Menular. Diunduh dari: http://www.bphn.go.id/data/documents/91pp0 40.pdf.

27. Bedeković T, Jankovic IL, Simic I, Kresic N, Lojkic I, sucec I, et al. Control and elimination of rabies in Croatia. PLoS ONE.2018; 13(9): e0204115. doi: 10.1371 /journal.pone. 0204115 .

28. Conan A, Kent A, Koman K, Konink S, Knobel D. Evaluation of methods for shortterm marking of domestic dogs for rabies control. Prev Vet Med. 2015; 121(1-2):17982. doi: 10.1016/j.prevetmed.2015.05.008. Epub 2015 Jun 1.

29. Lupulovic D, Maksimovic Zoric J, Vaskovic $\mathrm{N}$, Bugarski D, Plavsic B,Ivanović N, et al. First report on the efficiency of oral vaccination of foxes against rabies in Serbia. Zoonoses and Public Health.2015; 62(8): 625-36. doi: 10.1111/zph.12196.

30. Robardet E, Picard-Meyer E, Dobros `tana M, Jaceviciene I, Mahar K, Muiz `niece Z, et al. Rabies in the Baltic States: decoding a proces of control and elimanation. PLoSNegl Trop Dis.2016;10(2): e0004432. doi: 10.1371/journal.pntd.0004432.

31. Mortes M.K, S. Bharadwaja S, Whay HR, Cleaveland S, Damriyasa IMd, Wood JLN. Participatory methods for the assessment of the ownership status of free roaming dogs in Bali Indonesia, for diseases control and animal welfare. Preventive Veterinary Medicine.2014;116(1-2):2013-8. doi: 10.1016/j.prevetmed.2014.04.012.

32. Townsend SE, Sumarta IP, Pujiatmoko, Bagus G.N, Brum E, Cleaveland S, et al. Designing program for eliminating canine rabies from islands: Bali, Indonesia as a case study. Plos Negl Trop Dis. 2013;7(8):e2372. doi: 10.1371/journal.pntd.0002372.

33. Peraturan Pemerintah Nomor 68 Tahun 2005 
tentang Tata Cara Mempersiapkan Rancangan Undang-Undang, Rancangan Peraturan Pemerintah Pengganti Undangundang, Rancangan Peraturan Pemerintah, dan Rancangan Peraturan Presiden. Diunduh dari: http://jdih.kkp.go.id/peraturan/perpres-682005.pdf.

34. Suryadjaja C. Elemen-elemen pokok pembentukan peraturan daerah tentang penanggulangan HIV/AIDS. USAID. 2008. 